J. Dairy Sci. 95:4029-4040

http://dx.doi.org/10.3168/jds.2011-5275

(C) American Dairy Science Association ${ }^{\circledR}, 2012$.

\title{
Heat-treated colostrum and reduced morbidity in preweaned dairy calves: Results of a randomized trial and examination of mechanisms of effectiveness
}

\author{
S. M. Godden, ${ }^{11}$ D. J. Smolenski,† M. Donahue, ${ }^{2}$ J. M. Oakes,† R. Bey, ${ }^{\star}$ S. Wells, ${ }^{*}$ S. Sreevatsan, ${ }^{*}$ J. Stabel,‡ \\ and J. Fetrow* \\ ${ }^{*}$ Department of Veterinary Population Medicine, College of Veterinary Medicine, University of Minnesota, St. Paul 55108 \\ †Division of Epidemiology and Community Health, School of Public Health, University of Minnesota, Minneapolis 55454 \\ ¥USDA Agricultural Research Service, National Animal Disease Center, Ames, IA 50010
}

\begin{abstract}
A randomized controlled clinical trial was conducted using 1,071 newborn calves from 6 commercial dairy farms in Minnesota and Wisconsin, with the primary objective being to describe the effects of feeding heat-treated colostrum on serum immunoglobulin G concentration and health in the preweaning period. A secondary objective was to complete a path analysis to identify intermediate factors that may explain how feeding heat-treated colostrum reduced the risk for illness. On each farm, colostrum was collected each day, pooled, and divided into 2 aliquots; then, one aliquot was heat-treated in a commercial batch pasteurizer at $60^{\circ} \mathrm{C}$ for $60 \mathrm{~min}$. Samples of fresh and heat-treated colostrum were collected for standard microbial culture (total plate count and total coliform count, cfu/mL) and for measurement of immunoglobulin G concentrations $(\mathrm{mg} / \mathrm{mL})$. Newborn calves were removed from the dam, generally within 30 to 60 min of birth, and systematically assigned to be fed $3.8 \mathrm{~L}$ of either fresh $(\mathrm{FR}, \mathrm{n}=518)$ or heat-treated colostrum (HT, n = $553)$ within $2 \mathrm{~h}$ of birth. Venous blood samples were collected from calves between 1 and $7 \mathrm{~d}$ of age for measurement of serum IgG concentrations $(\mathrm{mg} / \mathrm{mL})$. All treatment and mortality events were recorded by farm staff between birth and weaning. Regression models found that serum IgG concentrations were significantly higher in calves fed HT colostrum $(18.0 \pm 1.5 \mathrm{mg} /$ $\mathrm{mL}$ ) compared with calves fed FR colostrum (15.4 \pm $1.5 \mathrm{mg} / \mathrm{ml}$ ). Survival analysis using Cox proportional hazards regression indicated a significant increase in risk for a treatment event (any cause) in calves fed FR colostrum $(36.5 \%$, hazard ratio $=1.25)$ compared with calves fed HT colostrum (30.9\%). In addition, we
\end{abstract}

Received December 19, 2011.

Accepted March 6, 2012.

${ }^{1}$ Corresponding author: godde002@umn.edu

${ }^{2}$ Current address: USDA-FSIS, Minneapolis District, Minneapolis, MN 55403. observed a significant increase in risk for treatment for scours in calves fed FR colostrum (20.7\%, hazard ratio $=1.32$ ) compared with calves fed HT colostrum (16.5\%). Path analysis suggested that calves fed HT colostrum were at lower risk for illness because the heat-treatment process caused a significant reduction in colostrum total coliform count, which was associated with a reduced risk for illness as a function of improved serum IgG concentrations.

Key words: bacteria, colostrum, morbidity, heattreatment

\section{INTRODUCTION}

The neonatal calf relies on the passive absorption of colostral immunoglobulins within the first few hours after birth to provide protection against infectious disease challenge early in life (Robison et al., 1988; Banks, 1993). Serum IgG concentrations $\geq 10 \mathrm{mg} / \mathrm{mL}$ at 24 to $48 \mathrm{~h}$ are associated with reduced risk for morbidity and mortality in the preweaning period, improved daily weight gain and feed efficiency, reduced age at first calving, and improved milk production later in life (Robison et al., 1988; DeNise et al., 1989; Wells et al., 1996; Donovan et al., 1998; Weaver et al., 2000; Faber et al., 2005). Despite the health and nutritional benefits for the calf, colostrum is a potential early source of exposure to microbial pathogens. Microorganisms may be present in colostrum from multiple sources, including secretion from the mammary gland; contamination during milking, storage, or feeding; or bacterial proliferation in stored colostrum (Fecteau et al., 2002; McGuirk and Collins, 2004; Stewart et al., 2005). Contamination of colostrum with microbial pathogens may result in acute or chronic disease, depending on the nature of the pathogen: Salmonella spp., Escherichia coli, Mycobacterium avium ssp. paratuberculosis (MAP), Mycoplasma spp., and bovine leukemia virus are just a few of the pathogens that may be isolated from colostrum (Ferrer and Piper, 1981; Streeter et al., 
1995; González and Wilson, 2003; CDC, 2008; Houser et al., 2008; Nielsen et al., 2008; Pithua et al., 2009). As an additional concern, some studies have reported that high concentrations of bacteria in colostrum may be associated with decreased immunoglobulin absorption, thereby contributing to failure of passive transfer (James et al., 1981; Poulson et al., 2002).

Heat treatment (HT) may be one approach to reduce microbial contamination in colostrum. The history of developing a technique to heat-treat colostrum has been reviewed elsewhere (Donahue et al., 2012). Briefly, $\mathrm{HT}$ at $60^{\circ} \mathrm{C}$ for 60 min significantly reduces or eliminates inoculated pathogens, including Mycoplasma bovis, Listeria monocytogenes, Escherichia coli, Salmonella enteritidis, and MAP, and significantly reduces total bacteria counts and total coliform counts in colostrum, while maintaining colostrum IgG concentrations and nutrient composition. This HT protocol has been validated in laboratory-based inoculation studies, in 2 separate single-herd university trials and, more recently, in a multiherd study conducted on 6 large commercial Upper Midwest dairy farms (McMartin et al., 2006; Godden et al., 2006; Johnson et al., 2007; ElizondoSalazar and Heinrichs, 2009a; Donahue et al., 2012).

Two single-herd university trials reported that calves fed HT colostrum experienced improved efficiency of IgG absorption and higher serum IgG concentrations as compared with calves fed the untreated, fresh (FR) colostrum (Johnson et al., 2007; Elizondo-Salazar and Heinrichs, 2009a). The mechanism to explain the relationship between feeding HT colostrum and improved passive transfer of IgG has not yet been determined. Although it has been suggested that bacteria present in the small intestine may interfere with the process of passive absorption of colostral immunoglobulins (James et al., 1976; James and Polan, 1978; James et al., 1981) to date, equivocal and limited evidence support this hypothesis (Poulson et al., 2002; Elizondo-Salazar and Heinrichs, 2009b).

In theory, reducing microbial exposure and enhancing the serum IgG status of calves fed HT colostrum should result in improved calf health. However, studies to date have lacked sufficient sample sizes to investigate this hypothesis. The first objective of the current study was to conduct a multiherd controlled clinical trial to describe the direct effects of feeding HT colostrum on passive transfer of IgG and on calf health, the hypothesis being that calves fed HT (vs. FR) colostrum would have improved serum IgG concentrations and would be at reduced risk for morbidity and mortality in the preweaning period. Assuming that a treatment effect was discovered, a secondary objective was to complete a path analysis to identify intermediate factors that may explain how feeding HT colostrum reduced risk for illness. The authors hypothesized that feeding HT colostrum would result in reduced illness either by reducing bacterial pathogen exposure or by enhancing serum IgG concentrations or both.

\section{MATERIALS AND METHODS}

\section{Farm Enrollment}

This study was approved by the University of Minnesota Institutional Animal Care and Use Committee (IACUC). Six large commercial dairy farms in Minnesota and Wisconsin were enrolled in the study during the summer of 2007. This was a convenience sample of herds, based on their proximity to the University of Minnesota ( $\sim 250 \mathrm{~km}$ radius), willingness to adhere to study protocols, and with at least one animal in the herd that tested positive for infection with MAP by fecal culture or serum ELISA within the previous 3 yr. Calf enrollment was from June to August 2007. The target sample size of $\geq 500$ calves per treatment group was calculated to allow for a sufficient number of adult animals to still be present in the herd 3 to 5 yr after enrollment, to address a longer term objective: evaluate the effect of feeding HT colostrum on risk for transmission of MAP.

\section{Colostrum Preparation}

First-milking colostrum was collected by farm personnel within $2 \mathrm{~h}$ postcalving and refrigerated at $4^{\circ} \mathrm{C}$ for 24 to $48 \mathrm{~h}$ before pooling. Refrigerated colostrum was pooled into one batch, thoroughly mixed, and divided into equal aliquots. One aliquot was left untreated whereas the other was heat-treated in a commercial batch pasteurizer at $60^{\circ} \mathrm{C}$ for $60 \mathrm{~min}$ (DairyTech Inc., Windsor, CO). Pasteurizers were programmed to heat colostrum to a target temperature of $60^{\circ} \mathrm{C}$ for $60 \mathrm{~min}$, with a maximum allowable fluctuation of $0.56^{\circ} \mathrm{C}$ during the 60-min holding phase. Colostrum was then automatically cooled to $15.6^{\circ} \mathrm{C}$. Times and temperatures were reported by digital display on the equipment during the heat-treatment process, but were not recorded due to lack of availability of electronic recording equipment for the batch pasteurizers used at the time the study was conducted (Note: electronic data loggers and paper chart recorders are currently available as an option for use with this equipment). Colostrum was agitated during the entire heat-treatment process. Duplicate 50$\mathrm{mL}$ aliquots of FR and HT colostrum were aseptically collected from each batch and frozen at $-20^{\circ} \mathrm{C}$ before analysis. The effects of HT on colostrum characteristics 
are reported in a companion manuscript (Donahue et al., 2012). Fresh and HT colostrum were transferred to sanitized 3.8-L bottles and refrigerated for later feeding to calves enrolled in the study. Colostrum was generally fed within 24 to $48 \mathrm{~h}$ of preparation.

\section{Calf Enrollment, Management, and Data Collection}

Newborn calves were enrolled between May 30 and August 23, 2007. All farms had 24-h supervision of the maternity area. Newborn calves were separated from the dam shortly after birth and before suckling. All liveborn heifer calves were eligible for enrollment on 5 farms. Both heifer and bull calves were enrolled on the sixth farm, which raised all calves to weaning age. Calves were systematically assigned by birth order to receive $3.8 \mathrm{~L}$ of $\mathrm{HT}$ or FR colostrum as soon as possible after birth (goal $<2 \mathrm{~h}$ ). Five farms fed the entire 3.8-L volume of colostrum by esophageal tube feeder, whereas 1 farm fed colostrum first by nipple bottle, with any remaining unconsumed colostrum fed via an esophageal tube feeder. One farm offered a second feeding of 1.9 $\mathrm{L}$ of colostrum by nipple bottle approximately $12 \mathrm{~h}$ after the first feeding, whereas the remaining 5 farms fed only a single colostrum feeding. Farm personnel recorded calf enrollment information, including dam identification number, calf identification number, birth date and time, colostrum treatment group assigned, colostrum batch fed, time of colostrum feeding, sex and number of calves born (single/twin), and calving ease score $(1=$ unassisted, $2=$ easy pull, $3=$ moderate pull, $4=$ hard pull, $5=$ caesarian section).

After the colostrum was fed, calves were moved to individual calf housing, either hutches (3 farms) or individual pens within a barn ( 3 farms), where they were managed according to each farm's routine feeding and management protocols. Farm personnel responsible for calf enrollment and colostrum feeding were not blinded to treatment assignment; however, farm personnel responsible for calf care to weaning were at a different physical location from the calf enrollment area, and were therefore effectively blinded to treatment. Farm staff recorded all treatment events, types of treatments administered, and mortality events between birth and weaning.

\section{Sample Collection and Analysis}

University technicians visited the study farms once per week to collect enrollment information, treatment and mortality records, and frozen colostrum samples. In addition, they collected a 1-mL blood sample from the jugular vein from all calves between 1 and $7 \mathrm{~d}$ of age. Blood and colostrum samples were transported on ice to the University of Minnesota (St. Paul) for analysis. Blood samples were centrifuged and serum collected and frozen at $-20^{\circ} \mathrm{C}$ until it could be analyzed for serum IgG concentration $(\mathrm{mg} / \mathrm{mL})$ by turbidometric immunoassay (Etzel et al., 1997). Frozen colostrum was thawed and colostrum IgG concentration was determined by turbidometric immunoassay. The second (duplicate) colostrum sample was submitted to the Laboratory for Udder Health (University of Minnesota) for bacterial culture. Colostrum samples were thawed to $4^{\circ} \mathrm{C}$, mixed by vortex, and serially diluted $1: 10$ for 5 dilutions. Each dilution was plated on plate count agar for total plate count (TPC) and on MacConkey agar for total coliform count (TCC). Plates were incubated for $48 \mathrm{~h}$ at $37^{\circ} \mathrm{C}$ and the number of colonies recorded $(\mathrm{cfu} / \mathrm{mL})$.

\section{Statistical Analysis for Objective 1: Effect of Feeding HT Colostrum on Serum IgG Concentration and Calf Health}

All analyses for this objective were performed using SAS software (version 9.2; SAS Institute, Cary, NC), with final significance declared at $P<0.05$. A calf was excluded from the analysis if it was reported as stillborn (i.e., died within $24 \mathrm{~h}$ of birth) or if it could not be matched to a specific batch and sample of colostrum fed (FR or HT) for which colostrum bacterial culture and $\operatorname{IgG}$ results were available. Descriptive statistics were generated to describe characteristics of study calves and the colostrum fed for both treatment groups.

General mixed linear regression (Proc MIXED) was used to describe the effect of treatment (FR vs. HT) on calf serum IgG $(\mathrm{mg} / \mathrm{mL})$. Initially, univariate models were created to test the effect of treatment (FR vs. $\mathrm{HT}$ ), age at first colostrum feeding (min), calving ease score (1 through 5$)$, IgG concentration in the colostrum fed $(\mathrm{mg} / \mathrm{mL})$, and age at blood sample collection (d). Sex of the calf was not considered in the models because bull calves were only enrolled on one farm. Even if differences existed in study outcomes between bulls and heifers, this still would not introduce a bias to study findings, as bull calves were randomly assigned to both FR and HT groups. Covariates significant at $P$ $<0.20$ in a univariate model were carried forward into a multivariate model. A backward stepwise approach was then used to create the final model to predict the outcome serum IgG. Farm was included in all models as a random effect to control for the clustering of calves within farm. All possible 2-way interaction terms were explored between significant covariates remaining in the model. 
Cox proportional hazards regression (Proc PHreg) was used to test the effect of treatment on the risk for (1) treatment for any disease event; (2) treatment for a scours event; (3) treatment for a respiratory disease event; or (4) death, in the preweaning period. Calves were censored at $56 \mathrm{~d}$ of age (weaning) if they did not experience the event of interest by that time. The covsandwich estimator was used to estimate robust standard errors that accounted for clustering at the farm level.

\section{Statistical Analysis for Objective 2: Path Analysis to Investigate How Feeding HT Colostrum Results in Reduced Risk for IIIness}

We hypothesized that feeding HT colostrum would result in reduced risk for illness either by reducing pathogen exposure (i.e., lower TPC or TCC) or by enhancing serum IgG concentrations, or both. Preliminary steps for this analysis used SAS software (version 9.1) and involved bivariate analyses to investigate all possible unconditional relationships between the variables describing colostrum treatment (FR vs. HT), colostral TPC $\left(\log _{10} \mathrm{cfu} / \mathrm{mL}\right)$, colostral TCC $\left(\log _{10} \mathrm{cfu} / \mathrm{mL}\right)$, serum $\operatorname{IgG}(\mathrm{mg} / \mathrm{mL})$, and risk for a treatment event in the preweaning period (treated/not treated). Linear regression (Proc MIXED) was used to develop those univariate models in which the outcome was continuous in nature (i.e., TPC, TCC, or IgG). Cox proportional hazards regression (Proc PHreg) was used to develop the univariate models in which the outcome was time to an illness event. For these models, the proportional hazards assumption was evaluated using standard graphical methods and a statistical assessment of the residuals (Kleinbaum and Klein, 2005). Herd was controlled for as a random effect in all models.

A series of path models was used to evaluate the hypotheses pursuant to the temporal effects of the experiment. In the first set of models, we considered whether TPC, TCC, or both functioned as intermediate variables of the effect of randomization to $\mathrm{FR}$ or HT colostrum and subsequent IgG measures. Mediation was assessed by examining the attenuation of the initial estimate between randomization and $\mathrm{IgG}$, the statistical significance of the component paths, and the estimated indirect effect (product of the component pathways) from the model indirect subcommand in Mplus version 6.1 (Muthén and Muthén, 2009). These initial mediation models were extended with 2 time-toevent outcomes: time to any illness and time to scours. Because these models specified all possible relationships between the variables included in the model, absolute model fit was, by definition, perfect, so standard tests of model fit for path analyses are not reported.

\section{RESULTS}

\section{Farm, Calf, and Colostrum Characteristics}

Mean (SD, range) herd size, rolling herd average, bulk tank SCC, and dry period length for the 6 participating herds were $1,617(454 ; 1,200$ to 2,500$)$ milking cows, $12,891(1,167 ; 11,280$ to 14,512$) \mathrm{kg}$ of milk, $280,983(99,986 ; 149,900$ to 430,000$)$ cells $/ \mathrm{mL}$, and 44 (3.7; 37 to 48) days dry, respectively. All 6 herds used freestall housing and housed predominantly Holstein cows, although a few crossbreds were represented. Five farms used group maternity pens and 1 used individual maternity pens. Four farms housed preweaned calves on the main farm, whereas 2 farms housed calves off-site. Five farms and 1 farm fed pasteurized whole milk or commercial powdered milk replacer (20:20 fat:protein, whey protein base, nonmedicated), respectively, until weaning. Free-choice starter pellet and water were offered on all farms by 3 to $5 \mathrm{~d}$ of age, and calves were routinely weaned between 7 and 8 wk of age.

Of 1,093 calves originally enrolled in the study, 6 were excluded from analysis because they were later defined as being stillborn (i.e., died within $24 \mathrm{~h}$ of birth). An additional 16 calves were excluded from analysis because they could not be matched to a specific batch and sample of colostrum fed (FR or HT) for which colostrum bacterial culture and $\operatorname{IgG}$ results were available. Final analysis was completed for 1,071 calves $(\mathrm{FR}=518 ; \mathrm{HT}=553)$. Calving ease scores, age at first feeding, colostrum IgG concentrations, and age at blood sample collection were not different between treatment groups (Table 1; $P>0.05$ ). As expected, the $\log _{10} \mathrm{cfu} / \mathrm{mL}$ TPC and TCC concentrations in the colostrum fed were significantly lower for calves fed $\mathrm{HT}(\mathrm{TPC}=3.5, \mathrm{TCC}=2.1)$ compared with calves fed FR $(\mathrm{TPC}=5.6, \mathrm{TCC}=4.7$; Table $1 ; P<0.05)$. Because of 24-h supervision of the calving area on all farms, removal from the dam and feeding of colostrum was generally very consistent and prompt: the mean age at first feeding for both treatment groups was 47.8 min, with $95 \%$ of calves fed colostrum within $2 \mathrm{~h}$ of birth.

\section{Objective 1: Effect of Feeding HT Colostrum on Serum IgG Concentration and Calf Health}

The analysis of effect of treatment on serum IgG concentration considered only 1,064 calves because serum samples were not available for 7 of the 1,071 calves, 5 of these because the calf died before a blood sample could be collected at the technician's weekly herd visit, and 2 because the sample went missing (lost or broken) in the laboratory. Calves with missing serum IgG 
Table 1. General characteristics of calves and the fresh and heat-treated colostrums ${ }^{1}$

\begin{tabular}{lcc}
\hline Variable & Fresh & Heat-treated \\
\hline Calves (no.) & 518 & 533 \\
Calving ease score $(1-5)$ & $1.4(0.74,1$ to 5$)$ & $1.4(0.74,1$ to 4$)$ \\
Age at first feeding (min) & $47.5(42.8,0$ to 520$)$ & $50.0(36.9,0$ to 195$)$ \\
Age at blood sample collection $(\mathrm{d})$ & $4.0(2.2,1$ to 9$)$ & $4.0(2.2,1$ to 8$)$ \\
In colostrum fed: & $63.9(20.4,16.3$ to 139.9$)$ & $61.1(19.2,12.1$ to 139.5$)$ \\
IgG $(\mathrm{mg} / \mathrm{mL})$ & $5.6(0.9,2.6$ to 9.1$)$ & $3.5(1.1,1$ to 8.4$)$ \\
Total plate count $\left(\log _{10}, \mathrm{cfu} / \mathrm{mL}\right)$ & $4.7(1.3,0$ to 6.8$)$ & $2.1(1.6,0$ to 7.0$)$ \\
Total coliform count $\left(\log _{10}, \mathrm{cfu} / \mathrm{mL}\right)$ & $515,000\left(390\right.$ to $\left.1.2 \times 10^{9}\right)$ & $2,100\left(10\right.$ to $\left.2.4 \times 10^{8}\right)$ \\
Total plate count ${ }^{2}(\mathrm{cfu} / \mathrm{mL})$ & $51,500\left(0\right.$ to $\left.6.7 \times 10^{6}\right)$ & $90\left(0\right.$ to $\left.9.5 \times 10^{6}\right)$ \\
Total coliform count ${ }^{2}(\mathrm{cfu} / \mathrm{mL})$ & &
\end{tabular}

measures were equally distributed between treatment groups $(\mathrm{FR}=3 ; \mathrm{HT}=4)$. Covariates associated with the dependent variable serum $\operatorname{IgG}(\mathrm{mg} / \mathrm{mL})$ in univariate models included colostrum treatment [estimate(SE) Fresh $=-2.39$ (0.37); $P<0.0001]$, IgG concentration in the colostrum fed [estimate $(\mathrm{SE})=0.11(0.0098) ; P$ $<0.0001]$, age at first feeding $[\operatorname{estimate}(\mathrm{SE})=-0.012$ $(0.0062) ; P=0.056]$, and age at blood sample collection [estimate $(\mathrm{SE})=-0.27(0.10) ; P=0.0064]$. However, only colostrum treatment group, IgG concentration in the colostrum fed, and age at blood collection were associated with serum IgG in the final multivariate model (Table 2). We observed no interactions among these 3 variables. The least squares means (SE) serum IgG concentration for calves fed FR and HT colostrum was $15.4(1.5)$ and $18.0(1.5) \mathrm{mg} / \mathrm{mL}$, respectively $(P<$ 0.0001; Table 2). Failure of passive transfer, defined as serum IgG $<10 \mathrm{mg} / \mathrm{mL}$, occurred in 30.1\% (156 of 518) and $18.6 \%$ (103 of 553) of calves fed FR and HT colostrum, respectively.

The analysis of effect of treatment on calf health outcomes considered all 1,071 calves. Colostrum treatment group (FR vs. HT: forced) was the only covariate remaining in any of the final survival models predicting risk for an illness or death event. Treatment had no effect on risk for treatment for a respiratory disease event or risk for a death event in the first $8 \mathrm{wk}$ of life (Table 3 ). However, we observed a significant increase in risk for treatment for any illness in calves fed FR colostrum $\left[36.5 \%\right.$, hazard ratio $\left.(\mathbf{H R})_{\text {Fresh }}=1.25\right]$ compared with calves fed HT colostrum (30.9\%; $P=0.002$; Table 3). In addition, we found a significant increase in risk for treatment for scours in calves fed FR colostrum $(20.7 \%$, $\mathrm{HR}_{\text {Fresh }}=1.32$ ) compared with calves fed HT colostrum (16.5\%; $P=0.0003$; Table 3).

\section{Objective 2: Path Analysis to Investigate How Feeding HT Colostrum Results in Reduced Risk for IIIness}

Preliminary bivariate analyses identified significant associations for each of the possible unconditional relationships examined among the variables describing colostrum treatment group, TPC, TCC, serum IgG, and risk for treatment for any illness or for scours in the preweaning period (Table 4). Specifically, in unconditional models, raw colostrum (FR) had a positive relationship with TPC, TCC, and risk for treatment for any illness or for scours, but a negative relationship with serum IgG (Table 4). Colostral TPC had a positive association with TCC and risk for treatment for any illness or for scours, but a negative association with serum IgG (Table 4). Colostral TCC had a positive association with risk for treatment for any illness or for scours, but a negative association with serum IgG (Figure 1, Table 4). Finally, serum IgG had a negative relationship with risk for treatment for any illness or for scours.

Table 2. Final multivariate model describing the effect of colostrum treatment (fresh vs. heat-treated) on calf serum IgG $(\mathrm{mg} / \mathrm{mL})^{1}$

\begin{tabular}{llccc}
\hline Covariate & Level & LSM (SE) & Estimate (SE) & $P$-value \\
\hline Intercept & & & $11.84(1.66)$ & 0.0009 \\
Colostrum treatment & Fresh & $15.4(1.5)$ & $-2.61(0.34)$ & $<0.0001$ \\
Colostrum IgG $(\mathrm{mg} / \mathrm{mL})$ & Heat-treated & $18.0(1.5)$ & Referent & $<0.0001$ \\
Age at blood sample (d) & & & $-0.22(0.0096)$ & 0.017 \\
\hline
\end{tabular}

${ }^{1}$ Herd controlled for as random effect. 
Table 3. Results from final models describing the effect of treatment (fresh, FR, vs. heat-treated, HT) on morbidity and mortality risk in preweaned dairy calves ${ }^{1}$

\begin{tabular}{|c|c|c|c|c|c|}
\hline Outcome parameter & $\begin{array}{l}\text { Treatment } \\
\text { group }\end{array}$ & $\begin{array}{c}\text { Affected, } \% \\
\text { (no.) }\end{array}$ & Estimate (SE) & $\begin{array}{l}\text { Hazard } \\
\text { ratio }_{\text {Fresh }}\end{array}$ & $P$-value \\
\hline Treatment for any disease & $\mathrm{FR}(\mathrm{n}=518)$ & $36.5(189)$ & $0.22(0.073)$ & $1.25(1.08,1.44)$ & 0.0022 \\
\hline Treatment for scours & $\mathrm{HT}(\mathrm{n}=553)$ & $16.5(91)$ & Referent & & \\
\hline \multirow{2}{*}{ Treatment for respiratory disease } & $\mathrm{FR}(\mathrm{n}=518)$ & $11.4(59)$ & $-0.00062(0.012)$ & $0.99(0.98,1.02)$ & 0.96 \\
\hline & $\mathrm{HT}(\mathrm{n}=553)$ & $9.4(52)$ & Referent & & \\
\hline
\end{tabular}

${ }^{1}$ Herd controlled for as random effect in all models.

The negative relationships between TPC or TCC and serum IgG were linear in nature (not curvilinear), with no optimal TPC or TCC cutpoint identified. Moreover, the strength and nature of this relationship (i.e., the slope of the regression lines) was the same for calves in both colostrum treatment groups (FR vs. HT; analysis not shown). The negative relationship between serum IgG concentration and risk for treatment for illness was also linear in nature (not curvilinear), with no optimal IgG cutpoint being evident for predicting illness. Finally, it should also be noted that when multivariate models were created predicting the outcome "risk for treatment for illness," which included variables describing TPC, TCC, or serum IgG as covariates along with colostrum treatment $(\mathrm{FR} / \mathrm{HT})$ in the model statement, the variable describing colostrum treatment consistently became nonsignificant and fell out of the model when using backward stepwise elimination (analysis not shown). This suggested that the association between colostrum treatment and risk for treatment for illness was confounded by TPC, TCC, and serum IgG, supporting the hypothesis that the protective effect of feeding heat-treated colostrum on calf health was mediated through the effect of reducing pathogen exposure (TPC, TCC) or improving serum IgG concentrations in the calf, or both. The results of this preliminary modeling led to the secondary objective of completing a formal path analysis to investigate how feeding heattreated colostrum results in reduced risk for illness.

Data from all 1,071 calves were used in developing the path models, as calves with missing data on outcomes included in the path models (i.e., 7 calves missing serum IgG measures) were retained for estimation through full information maximum likelihood. The initial path models indicated that TCC was superior to TPC in explaining the covariation between treatment assignment and serum IgG (Figure 2). With TPC specified as the intermediate variable, we observed a statistically significant association only between treatment assignment and TPC. The remaining direct effect between treatment and serum IgG was attenuated and not statistically significant. The estimated indirect association between treatment and serum IgG as a function of TPC was $-1.52(95 \% \mathrm{CI}=-4.00,0.96)$. In contrast, speci-

Table 4. Unconditional (crude) relationships among variables describing colostrum treatment group (fresh vs. heat-treated), colostral total plate count (TPC), colostral total coliform count (TCC), calf serum IgG, and risk for treatment for any illness event or for scours in the preweaning period (treated/not treated) $)^{1,2}$

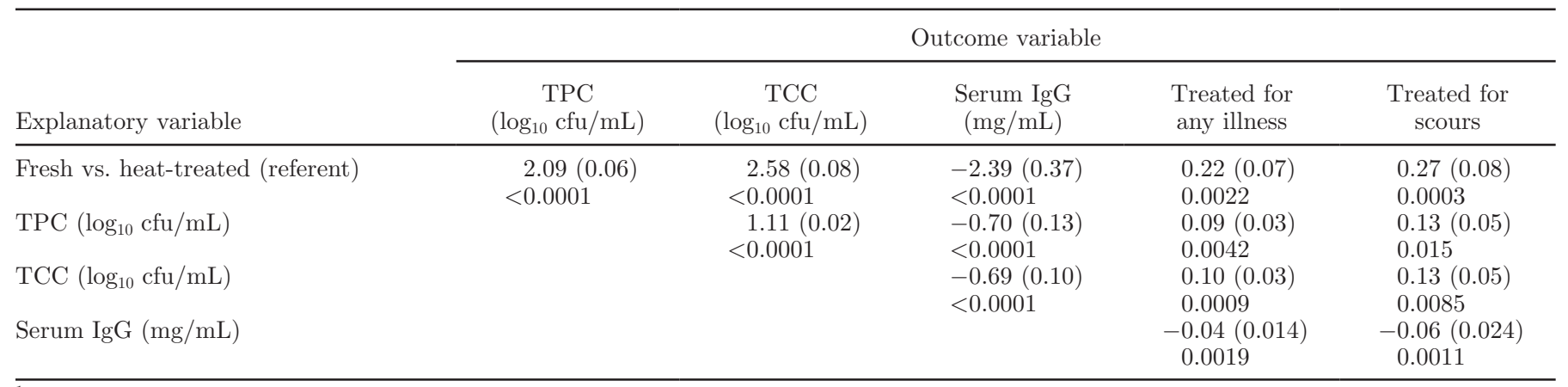

${ }^{1}$ Values reported are the parameter estimates (SE in parentheses) and $P$-values (below) for the explanatory variable, as derived from bivariate linear regression models where outcomes were TPC, TCC, or serum IgG, or from Cox proportional hazards regression models, where the outcome was risk for treatment for any illness or for scours.

${ }^{2}$ Herd controlled for as random effect in all models. 


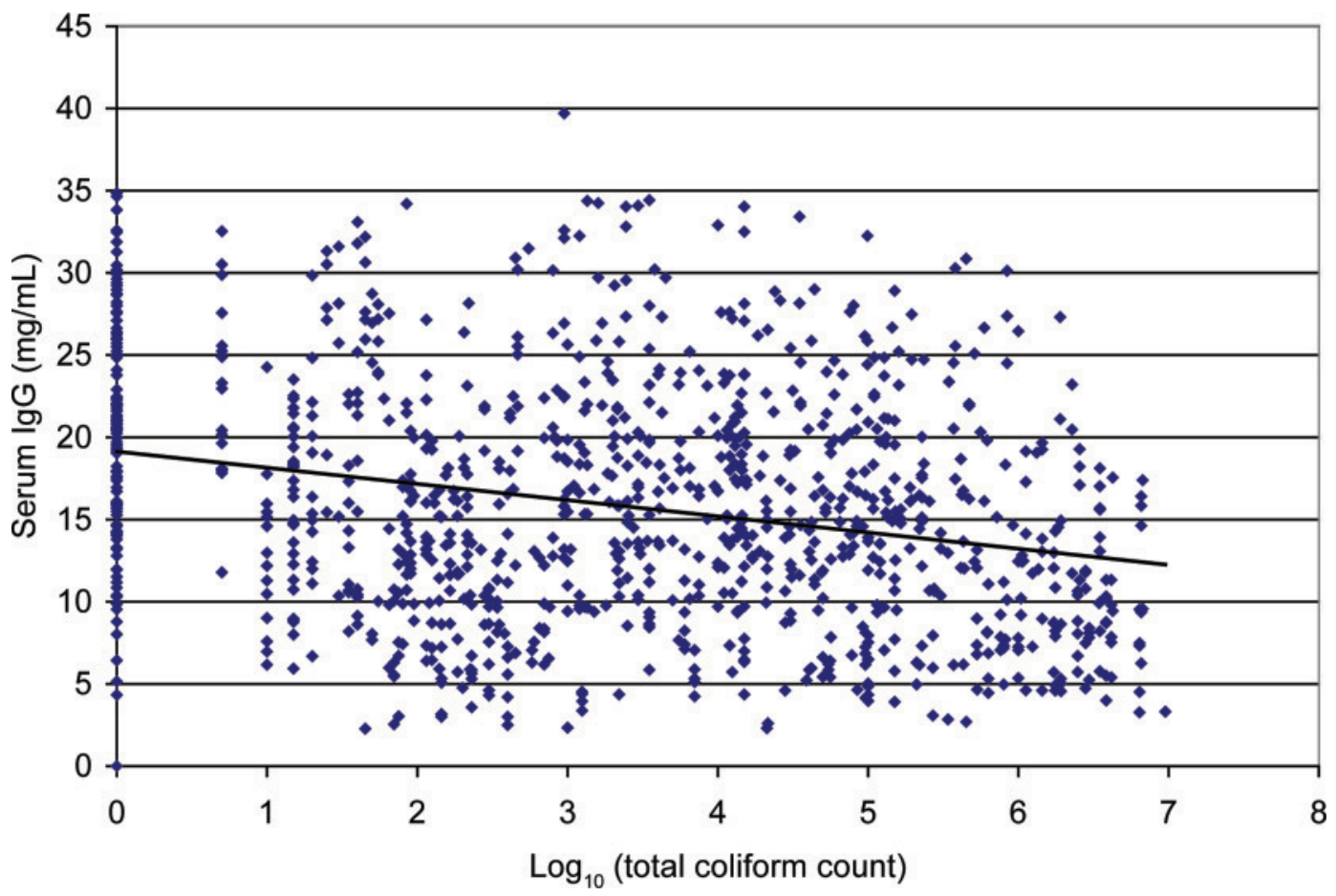

Figure 1. Scatter plot showing negative relationship between colostrum total coliform count $\left(\log _{10} \mathrm{cfu} / \mathrm{mL}\right)$ and calf serum IgG (mg/mL); $P$ $<0.0001$. Color version available in the online PDF.

fication of TCC as the intermediate variable yielded statistically significant associations between treatment and TCC and between TCC and IgG. The attenuation of the direct association between treatment assignment and serum IgG was stronger than when using TPC as the intermediate variable. The estimated indirect effect was $-2.47(95 \% \mathrm{CI}=-5.45,0.50)$. Given the reduced power associated with statistical inference of compound pathways (MacKinnon et al., 2000), the significance of both constituent pathways and the attenuation of the effect of treatment assignment on serum IgG to almost unity led us to conclude that TCC was the superior explanatory variable for the lower IgG levels observed for calves randomized to raw colostrum.

Subsequent path models that included time-to-event outcomes (days to treatment for any illness, days to treatment for scours) demonstrated that the association between treatment assignment, TCC, and the outcome (any illness or scours) was a function of serum IgG (Figure 3). For both outcomes, calves assigned to raw colostrum had higher TCC values, which were associated with lower serum $\operatorname{IgG}$ values. Accounting for the association between treatment assignment and TCC, and between TCC and serum IgG attenuated the observed total effect of treatment assignment on rates of any illness or scours to values indistinguishable from unity. This suggests that the higher infectious load and subsequent reduction in immunity in the FR calves is a plausible explanation for the observed effect of the treatment on calf health.

\section{DISCUSSION}

This is the first clinical trial designed to investigate the effect of feeding HT colostrum on calf health. Although this was a convenience sample of 6 large Midwest Holstein herds, the study results should be reasonably generalizable to other large commercial North American dairy herds. National US statistics estimate that the proportions of preweaned calves with failure of passive transfer, treated for scours or other digestive problems, and treated for respiratory disease are 19.2, 17.9, and $11.4 \%$, respectively (USDA-APHIS, 2007a; Beam et al., 2009). By comparison, the proportions of control calves (FR group) in the current study with failure of passive transfer, treated for scours, and treated for respiratory disease were $30.1,20.7$, and $11.4 \%$, respectively. Study herds did differ from national reported averages in some respects. For example, although the 6 study herds reported an average of $44 \mathrm{~d}$ dry, national US statistics report an average of $57.8 \mathrm{~d}$ dry (USDA-APHIS, 2007b). Furthermore, even though preweaning morbidity rates were comparable, the preweaning mortality rate in the control group (1.7\%) was lower than that in national 

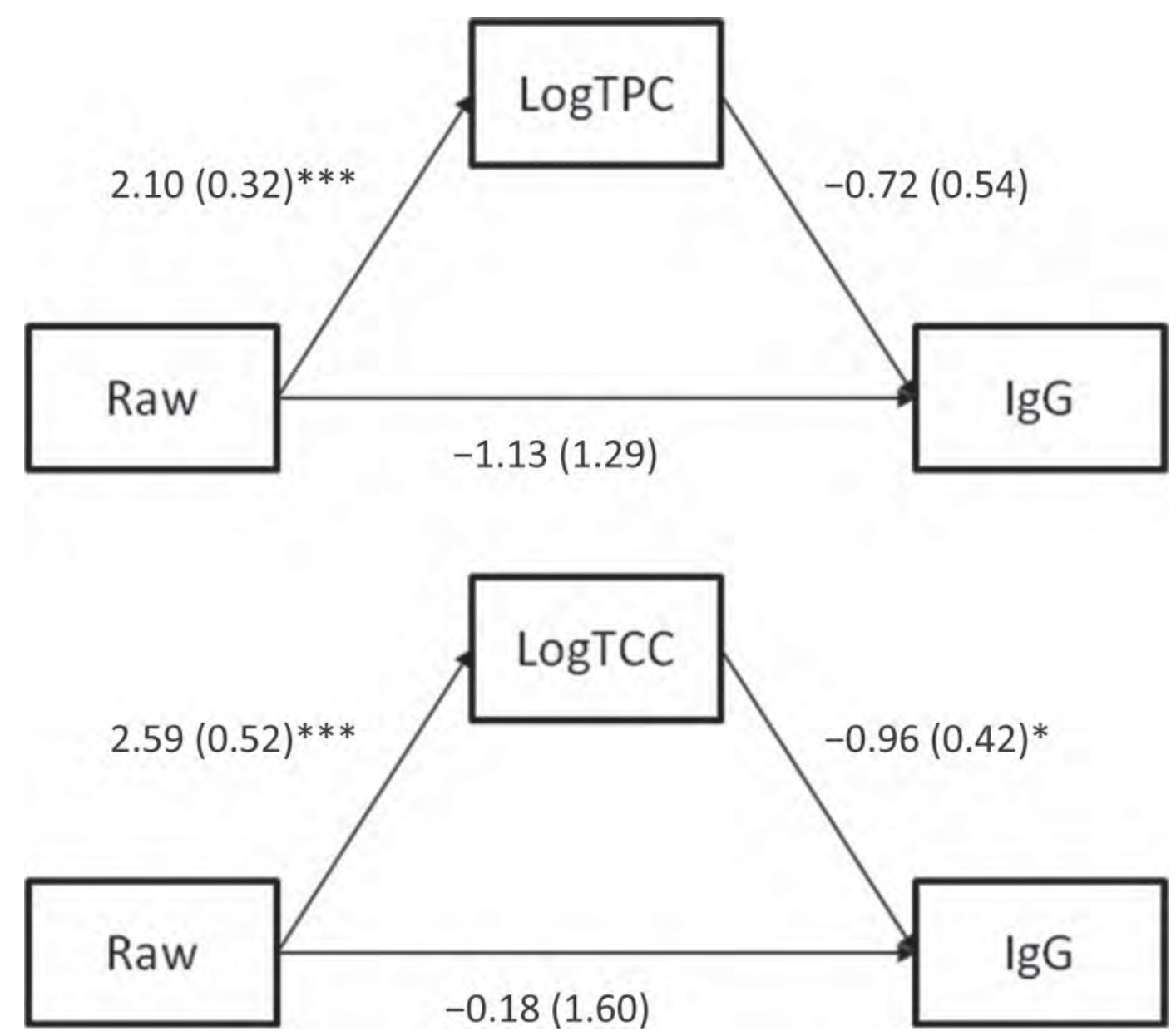

Figure 2. Path models of the direct and indirect effects of feeding fresh (raw) colostrum on serum IgG as a function of total plate count (TPC) and total coliform count (TCC). Feeding heat-treated colostrum was the referent. Values reported are the parameter estimates (SE) for the explanatory variable. ${ }^{*} P<0.05 ;{ }^{* * *} P<0.001$.

US statistics (7.8\%; USDA-APHIS, 2007a). The latter could reflect differences in the level of management on study dairies, but probably also reflects the fact that the current study was conducted in the summer months, when mortality rates in upper Midwest dairies are typically lowest. By comparison, the national statistics report an annual mortality rate.

In the current study, serum IgG concentrations were higher for calves fed HT colostrum $(18.0 \mathrm{mg} / \mathrm{mL})$ than for calves fed FR colostrum $(15.4 \mathrm{mg} / \mathrm{mL})$. These results are consistent with 2 earlier single-herd studies (Johnson et al., 2007; Elizondo-Salazar and Heinrichs, 2009a). This is an important finding as it demonstrates that the results of the aforementioned, tightly controlled, single-herd university studies were repeatable when the protocol for heat-treating colostrum at $60^{\circ} \mathrm{C}$ for 60 min was conducted by farm staff on multiple commercial dairy herds. Because the aforementioned studies measured birth weights on calves, they were able to calculate and report that the apparent efficiency of absorption of IgG was significantly improved in calves fed HT colostrum. It was a limitation of the current study that electronic birth weights were not available for calves from the 6 study herds, and so the apparent efficiency of absorption of IgG could not be calculated. Another limitation of the study was that colostrum was not resampled for microbiological culture immediately before feeding, as this would have added significantly to project costs and to protocol complexity for calf feeders. Although some bacterial growth is expected to occur between initial preparation and later feeding of a batch, this additional growth should be low and, because it would occur in both HT and FR colostrum, should not bias the study findings.

A novel and important finding of the current study was that calves fed FR colostrum were at significantly higher risk for treatment for illness (any cause) ( $\mathrm{HR}=$ 1.25; $P=0.0022)$ and for treatment for scours $(\mathrm{HR}=$ 

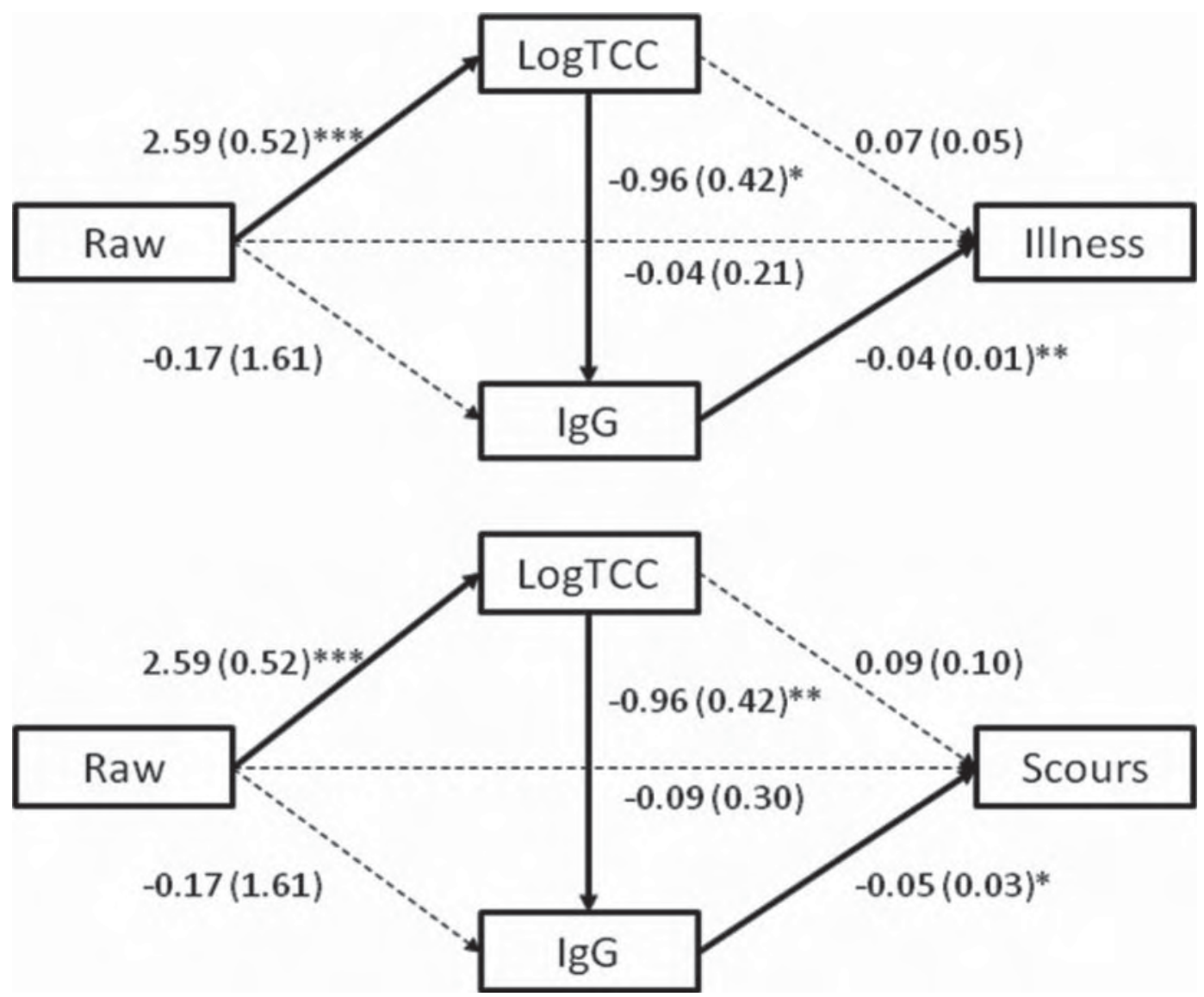

Figure 3. Final path models of feeding fresh (raw) colostrum and time-to-event outcomes as a function of total coliform count (TCC) and serum IgG. Feeding heat-treated colostrum was the referent. Values reported are the parameter estimates (SE) for the explanatory variable. ${ }^{*} P<0.05 ;{ }^{*} P<0.01 ;{ }^{* * *} P<0.001$.

$1.32 ; P=0.0003)$ compared with calves fed HT colostrum. This finding prompted the authors to complete a path analysis to identify intermediate factors that may explain the relationship between feeding HT colostrum and calf health, the hypothesis being that this was attributable to reduced bacterial pathogen exposure, enhanced serum IgG concentrations, or both. In the original work credited with originating this hypothesis, it was reported that when viable bacteria were present in the small intestine at the time of arrival of $\gamma$-globulin protein, the number of bacteria per gram of tissue was negatively correlated with globulin uptake, and that $\gamma$-globulin uptake was lowest in segments of intestine receiving live bacteria compared with segments receiving sterile inocula (James et al., 1981). This hypothesis was later supported by an observational study of 101 calves, in which calves fed raw colostrum with a high bacteria count experienced lower levels of passive transfer compared with calves fed raw colostrum with a low bacteria count (Poulson et al., 2002). However, a more recent study reported no difference in serum IgG concentrations in 10 calves fed high-bacterial-load raw colostrum (mean $\mathrm{SPC}=5.61 \log _{10} \mathrm{cfu} / \mathrm{mL}$ ) compared with 10 calves fed low-bacterial-load raw colostrum (mean $\mathrm{SPC}=3.97 \log _{10} \mathrm{cfu} / \mathrm{mL}$; Elizondo-Salazar and Heinrichs, 2009b). However, it is possible that the latter study failed to detect a relationship between colostral bacteria counts and IgG absorption due to a relatively small sample size or a relatively narrow biological range in colostrum bacterial counts for the 2 treatment groups compared.

The path analysis conducted in the current study supports the hypothesis that IgG absorption is negatively associated with colostrum bacteria counts. It was interesting that the variable TCC (and not TPC) was most strongly associated with serum IgG and, subsequently, with calf health. Although TPC and TCC were highly correlated (Pearson $\mathrm{r}=0.85 ; P<0.0001$ ), TCC may have produced a better model fit to predict IgG and risk for illness because a greater proportion of the total microbial population contributing to TCC would include pathogenic coliforms, compared with TPC, 
in which the pathogenic coliforms would be relatively more diluted by noncoliform bacteria. Although this hypothesis cannot be further investigated in the current study, the fact that TCC was most strongly associated with reduced serum IgG and impaired health is biologically consistent with previously proposed mechanism(s) that might explain the negative relationship between colostrum bacteria counts and IgG absorption: (1) pathogenic bacteria may be bound and neutralized by colostral immunoglobulins in the lumen of the small intestine, thereby decreasing the total mass of fed immunoglobulin available for absorption; (2) pathogenic bacteria (e.g., E. coli) may attach to and damage intestinal epithelial cells, thereby reducing permeability to immunoglobulin molecules; (3) damage to intestinal epithelial cells by pathogenic bacteria (e.g., E. coli) may result in enhanced replacement of permeable cells by cells incapable of macromolecular uptake (i.e., accelerated gut closure); or (4) nonspecific pinocytosis of bacteria could physically block absorption of immunoglobulin molecules (Corley et al., 1977; James et al., 1981). Although the mechanism(s) to explain the negative relationship between colostral bacteria counts and passive transfer of $\operatorname{IgG}$ requires further study, the current study shows this relationship to be real. Furthermore, this explains why calves fed HT colostrum had improved health compared with calves fed FR colostrum, because it is widely accepted that improved serum IgG status results in reduced risk for health problems in neonatal calves (Robison et al., 1988; Banks, 1993; Wells et al., 1996).

Of interest is that the path analysis suggested that the entirety of the health benefits observed in calves fed HT colostrum was mediated through the reduction in TCC and its association with improved serum IgG concentrations. Unexpectedly, the analysis did not show any additional direct association between TCC and risk for an illness event. It would be reasonable to expect that the latter relationship might still be true in some herds and under some conditions in which specific pathogenic bacteria might be shed intermittently or in disease outbreaks in fresh cows (e.g., Salmonella spp., Mycoplasma spp.). It is possible that the current study did not observe such a relationship because cows calving during the 3-mo enrollment window for the current study might not have been shedding important pathogens in their colostrum with enough frequency or concentration to cause significant calfhood diseases. Unfortunately, this hypothesis cannot be further investigated because, due to budget constraints, we were unable to culture colostrum for specific known pathogens such as Salmonella spp. or Mycoplasma spp.

One consideration requiring further study is the effect of heat treatment on viability of colostral leukocytes and the clinical significance of this to the calf. Colostral leukocytes are known to be absorbed by the neonatal intestine and reach the lymphoid tissue and circulation (Liebler-Tenorio et al., 2002; Reber et al., 2006), where they may play a role in enhancing the development of the neonatal immune system (Donovan et al., 2007; Reber et al., 2008a,b). However, studies are lacking to describe the potential clinical effect of not feeding maternal leukocytes. A recent laboratory-based study that used a prototype colostrum pasteurizer reported that the heat-treatment process significantly reduced the viability of colostral leukocytes (Koewler et al., 2010). Because the HT calves in the current study experienced reduced morbidity compared with FR calves, it must be concluded that the benefit of reducing colostrum bacteria counts outweighed the potential (and as yet unmeasured) cost of reducing the concentration of viable colostral leukocytes. Studies are needed to learn more about the role and clinical significance of colostral leukocytes to neonatal calves.

Given that calves fed HT colostrum had improved serum IgG concentrations and reduced risk for illness in the preweaning period, other longer-term benefits from feeding HT colostrum might exist. Several studies have reported that, besides the reduced risk for preweaning morbidity and mortality, additional long-term benefits associated with successful passive transfer include reduced mortality in the postweaning period, improved rate of gain and feed efficiency, reduced age at first calving, improved first- and second-lactation milk production, and reduced tendency for culling during the first lactation (Robison et al., 1988; DeNise et al., 1989; Wells et al., 1996; Faber et al., 2005). Furthermore, because MAP can be shed in the colostrum of subclinically infected cows, another potential benefit of feeding HT colostrum could be reduced risk for transmission of MAP (Streeter et al., 1995; Godden et al., 2006; Nielsen et al., 2008; Pithua et al., 2009). We are currently in the process of investigating this hypothesis by following study animals through to the end of their third lactation to collect records of milk production and longevity, and to conduct annual testing for infection with MAP.

Implications from the current study are that producers should strive to reduce the level of bacterial contamination in colostrum fed to newborn calves. This may be achieved through a variety of management strategies, including discarding colostrum from known infected cows; not feeding pooled raw colostrum; proper udder preparation before colostrum harvest; proper cleaning and sanitation of all colostrum milking, storage, or feeding equipment; rapid chilling or freezing of stored colostrum; the use of preservatives; feeding commercial colostrum replacement products; and, the 
topic of the current study, heat treatment of colostrum (Stewart et al., 2005; Godden et al., 2006; McMartin et al., 2006; Nielsen et al., 2008; Pithua et al., 2009; Donahue et al., 2012). Experts have suggested that a goal should be to harvest and feed colostrum with TPC and TCC of $<100,000$ and $<10,000 \mathrm{cfu} / \mathrm{mL}$, respectively (McGuirk and Collins, 2004). Even though TPC and TCC are known to be highly correlated, the results of this study suggest that if a producer were to select only one parameter to monitor, then periodic culture of colostrum for TCC might be a better predictor of disease. Furthermore, although consistently achieving a TCC $<10,000 \mathrm{cfu} / \mathrm{mL}\left(\log _{10}=4.0\right)$ would be a reasonable goal for many producers (McGuirk and Collins, 2004) (the mean $\log _{10}$ TCC in FR colostrum from the current study was 4.7 ), the fact that we observed a negative linear relationship between TCC and serum IgG suggests there is no optimal cutpoint for TCC: the lower the better.

\section{CONCLUSIONS}

Calves fed HT colostrum had significantly higher serum IgG concentrations and were at significantly lower risk for treatment for scours and treatment for any illness in the preweaning period compared with calves fed FR colostrum. Path analysis illustrated that calves fed HT colostrum were at lower risk for illness because the heat-treatment process caused a significant reduction in colostrum TCC, which was associated with a reduced risk for illness as a function of improved serum IgG concentrations.

\section{ACKNOWLEDGMENTS}

This study was funded by a grant from the USDACSREES. The authors thank the owners and managers of the 6 dairy herds for their participation and support. We also thank Amber Hazel (College of Veterinary Medicine, University of Minnesota. St. Paul), Eb Ballinger (Cornell Veterinary Clinic, Cornell, WI), Jennifer Belz (Pierce Veterinary Clinic. Ellsworth, WI), and Katie Konkol (Mrdutt) (Bovine Veterinary Clinic. Ridgeland, WI) for their technical assistance.

\section{REFERENCES}

Banks, W. J. 1993. Pages 457-461 in Applied Veterinary Histology. 3rd ed. Mosby Year Book Inc., St. Louis, MO.

Beam, A. L., J. E. Lombard, C. A. Kopral, L. P. Garber, A. L. Winter, J. A. Hicks, and J. L. Schlater. 2009. Prevalence of failure of passive transfer of immunity in newborn heifer calves and associated management practices on US dairy operations. J. Dairy Sci. 92:3973-3980.
CDC. 2008. Escherichia coli O157:H7 infections in children associated with raw milk and raw colostrum from cows-California, 2006. MMWR Morb. Mortal. Wkly. Rep. 57:625-628.

Corley, L. D., T. E. Staley, L. J. Bush, and E. W. Jones. 1977. Influence of colostrum on transepithelial movement of Escherichia coli 055. J. Dairy Sci. 60:1416-1421.

DeNise, S. K., J. D. Robison, G. H. Stott, and D. V. Armstrong. 1989. Effects of passive immunity on subsequent production in dairy heifers. J. Dairy Sci. 72:552-554.

Donahue, M., S. M. Godden, R. Bey, S. Wells, J. M. Oakes, J. Fetrow, S. Sreevatsan, and J. Stabel. 2012. Heat-treatment of colostrum on commercial dairy farms reduces colostrum microbial counts while maintaining colostrum immunoglobulin G concentrations. J. Dairy Sci. 95:2697-2702.

Donovan, D. C., A. J. Reber, J. D. Gabbard, M. Aceves-Avila, K. L. Galland, K. A. Holbert, L. O. Ely, and D. J. Hurley. 2007. Effect of maternal cells transferred with colostrum on cellular responses to pathogen antigens in neonatal calves. Am. J. Vet. Res. 68:778-782.

Donovan, G. A., I. R. Dohoo, D. M. Montgomery, and F. L. Bennett. 1998. Associations between passive immunity and morbidity and mortality in dairy heifers in Florida, USA. Prev. Vet. Med. 34:31-46.

Elizondo-Salazar, J. A., and A. J. Heinrichs. 2009a. Feeding heattreated colostrum to neonatal dairy heifers: Effects on growth characteristics and blood parameters. J. Dairy Sci. 92:3265-3273.

Elizondo-Salazar, J. A., and A. J. Heinrichs. 2009b. Feeding heattreated colostrum or unheated colostrum with two different bacterial concentrations to neonatal dairy calves. J. Dairy Sci. 92:4565-4571.

Etzel, L. R., R. E. Strohbehn, and J. K. McVicker. 1997. Development of an automated turbidimetric immunoassay for quantification of bovine serum immunoglobulin G. Am. J. Vet. Res. 58:1201-1205.

Faber, S. N., N. E. Faber, T. C. McCauley, and R. L. Axe. 2005 Effects of colostrum ingestion on lactational performance. Prof. Anim. Sci. 21:420-425.

Fecteau, G., P. Baillargeon, R. Higgins, J. Paré, and M. Fortin. 2002. Bacterial contamination of colostrum fed to newborn calves in Québec dairy herds. Can. Vet. J. 43:523-527.

Ferrer, J. F., and C. E. Piper. 1981. Role of colostrum and milk in the natural transmission of the bovine leukemia virus. Cancer Res. 41:4906-4909.

Godden, S., S. McMartin, J. Feirtag, J. Stabel, R. Bey, S. Goyal, L. Metzger, J. Fetrow, S. Wells, and H. Chester-Jones. 2006. Heattreatment of bovine colostrum. II: Effects of heating duration on pathogen viability and immunoglobulin G. J. Dairy Sci. 89:34763483.

González, R. N., and D. J. Wilson. 2003. Mycoplasmal mastitis in dairy herds. Vet. Clin. North Am. Food Anim. Pract. 19:199-221.

Houser, B. A., S. C. Donaldson, S. I. Kehoe, A. J. Heinrichs, and B. M. Jayarao. 2008. A survey of bacteriological quality and the occurrence of Salmonella in raw bovine colostrum. Foodborne Pathog. Dis. $5: 853-858$.

James, R. E., and C. E. Polan. 1978. Effect of orally administered duodenal fluid on serum proteins in neonatal calves. J. Dairy Sci. 61:1444-1449.

James, R. E., C. E. Polan, T. L. Bibb, and B. E. Laughon. 1976. Effect of orally administered duodenal fluid on susceptibility of newborn calves to an Escherichia coli challenge. J. Dairy Sci. 59:1495-1501.

James, R. E., C. E. Polan, and K. A. Cummins. 1981. Influence of administered indigenous microorganisms on uptake of [iodine-125] gamma-globulin in vivo by intestinal segments of neonatal calves. J. Dairy Sci. 64:52-61.

Johnson, J. L., S. Godden, T. Molitor, T. Ames, and D. Hagman. 2007. Effects of feeding heat-treated colostrum on passive transfer of immune and nutritional parameters in neonatal dairy calves. J. Dairy Sci. 90:5189-5198.

Kleinbaum, D. G., and M. Klein. 2005. Survival Analysis: A SelfLearning Text. 2nd ed. Springer, New York, NY. 
Koewler, N., S. Godden, T. Molitor, P. Rapnicki, R. Bey, and D. Haines. 2010. Heat-treatment of colostrum decreases maternal leukocyte viability. Pages 99-102 in Proc. Minnesota Dairy Conference 2010, St. Paul, MN. University of Minnesota, College of Veterinary Medicine, St. Paul.

Liebler-Tenorio, E. M., G. Riedel-Caspari, and J. F. Pohlenz. 2002. Uptake of colostral leukocytes in the intestinal tract of newborn calves. Vet. Immunol. Immunopathol. 85:33-40.

MacKinnon, D. P., J. L. Krull, and C. M. Lockwood. 2000. Equivalence of the mediation, confounding and suppression effect. Prev. Sci. 1:173-181.

McGuirk, S. M., and M. Collins. 2004. Managing the production, storage, and delivery of colostrum. Vet. Clin. North Am. Food Anim. Pract. 20:593-603.

McMartin, S., S. Godden, L. Metzger, J. Feirtag, R. Bey, J. Stabel, S. Goyal, J. Fetrow, S. Wells, and H. Chester-Jones. 2006. Heattreatment of bovine colostrum. I: Effects of temperature on viscosity and immunoglobulin G. J. Dairy Sci. 89:2110-2118.

Muthén, L., and B. Muthén. 2009. Mplus. Version 6.1. Muthén \& Muthén, Los Angeles, CA.

Nielsen, S. S., H. Bjerre, and N. Toft. 2008. Colostrum and milk as risk factors for infection with Mycobacterium avium subspecies paratuberculosis in dairy cattle. J. Dairy Sci. 91:4610-4615.

Pithua, P., S. M. Godden, S. J. Wells, and M. J. Oakes. 2009. Efficacy of feeding plasma-derived commercial colostrum replacer for the prevention of transmission of Mycobacterium avium subsp. paratuberculosis in Holstein calves. J. Am. Vet. Med. Assoc. 234:11671176.

Poulson, K. P., F. A. Hartmann, and S. M. McGuirk. 2002. Bacteria in colostrum: Impact on calf health. Page 773 in Proc. 20th Annual Am. Coll. Vet. Intern. Med. American College of Veterinary Internal Medicine (ACVIM), Lakewood, CO

Reber, A. J., D. C. Donovan, J. Gabbard, K. Galland, M. Aceves-Avila, K. A. Holbert, L. Marshall, and D. J. Hurley. 2008a. Transfer of maternal colostral leukocytes promotes development of the neonatal immune system: I. Effects on monocyte lineage cells. Vet. Immunol. Immunopathol. 123:186-196.
Reber, A. J., D. C. Donovan, J. Gabbard, K. Galland, M. Aceves-Avila, K. A. Holbert, L. Marshall, and D. J. Hurley. 2008b. Transfer of maternal colostral leukocytes promotes development of the neonatal immune system: II. Effects on neonatal lymphocytes. Vet. Immunol. Immunopathol. 123:305-313.

Reber, A. J., A. Lockwood, A. R. Hippen, and D. J. Hurley. 2006. Colostrum induced phenotypic and trafficking changes in maternal mononuclear cells in a peripheral blood leukocyte model for study of leukocyte transfer to the neonatal calf. Vet. Immunol. Immunopathol. 109:139-150.

Robison, J. D., G. H. Stott, and S. K. DeNise. 1988. Effects of passive immunity on growth and survival in the dairy heifer. J. Dairy Sci. $71: 1283-1287$.

Stewart, S., S. Godden, R. Bey, P. Rapnicki, J. Fetrow, R. Farnsworth, M. Scanlon, Y. Arnold, L. Clow, K. Mueller, and C. Ferrouillet. 2005. Preventing bacterial contamination and proliferation during the harvest, storage and feeding of fresh bovine colostrum. J Dairy Sci. 88:2571-2578.

Streeter, R. N., G. F. Hoffsis, S. Bech-Nielsen, W. P. Shulaw, and D. M. Rings. 1995. Isolation of Mycobacterium paratuberculosis from colostrum and milk of subclinically infected cows. Am. J. Vet. Res. 56:1322-1324.

USDA-APHIS. 2007a. Dairy: Heifer Calf Health and Management Practices on U.S. Dairy Operations, 2007. Accessed Jun. 30, 2010. http://www.aphis.usda.gov/animal_health/nahms/dairy/index. shtml.

USDA-APHIS. 2007b. Dairy: Part I: Reference of dairy cattle health and management practices in the United States, 2007. Accessed Feb. 8, 2012. http://www.aphis.usda.gov/animal_health/nahms/ dairy/downloads/dairy07/Dairy07_dr_PartI.pdf.

Weaver, D. M., J. W. Tyler, D. C. VanMetre, D. E. Hostetler, and G. M. Barrington. 2000. Passive transfer of colostral immunoglobulins in calves. J. Vet. Intern. Med. 14:569-577.

Wells, S. J., D. A. Dargatz, and S. L. Ott. 1996. Factors associated with mortality to 21 days of life in dairy heifers in the United States. Prev. Vet. Med. 29:9-19. 